\title{
LEONARD HORNER: \\ A PORTRAIT OF \\ AN INSPECTOR OF FACTORIES
}

Leonard Horner was the most impressive and influential of the first English factory inspectors. For 26 years from 1833 to 1859 he administered the Factory Act mainly in the textile district of Lancashire. His work and that of his colleagues in the Factory Department made a success of this major experiment in legislative intervention in industry and despite the gloomy predictions of their early opponents they did not ruin the British economy in the process. The first generation of Inspectors laid the foundation for successive extensions of the Factory Act so that by the end of the 19th century working conditions and hours of labour for women and children were under legal regulation in all the major branches of manufacturing industry. Horner was acknowledged by his contemporaries to be the major figure among the early Inspectors; he even had the singular honour of being praised by Marx in Capital. This short biography will concentrate on Horner's work as Inspector of Factories since this is undoubtedly his major achievement. However it will also be concerned with other aspects of his life and interests, both because these have some importance in their own right and also in order to examine the extent to which Horner's life and thought form a coherent whole. Finally, an assessment will be made of Horner's place in social reform and in the development of English economic and social policy in the 19th century.

HORNER'S EARLY LIFE AND CAREER ${ }^{1}$

Leonard Horner was born in Edinburgh in 1785 . He was the younger son of John Horner, a prosperous linen merchant, with family connections in landholding and the law. John Horner was a prominent

1 Unless otherwise stated the information in the follow-account is derived from A Memoir of Leonard Horner, edited by Katherine Lyell, Horner's daughter (hereafter referred to as the Memoir). It is in two volumes and was privately 
member of the Whig upper-middle class of Edinburgh and from their earliest years his children were brought up to be at ease in the highlyeducated and politically active coteries which formed the focus of the social life of their class. Francis and Leonard Horner attended first the High School and then the University of Edinburgh. Although Francis was seven years Leonard's senior their relationship was a close one. Through his brother, Leonard became intimate with that remarkable group of Whigs who with Francis Horner founded the Speculative Society and the Edingburgh Review, and distinguished themselves in public life from their student days onwards. This group included James Mill and Henry, later Lord Brougham with whom Leonard Horner was to be associated in the new University of London, Francis Jeffrey later Lord Advocate for Scotland through whom he became Inspector of Factories, and Henry, later Lord Cockburn with whom he founded the Edinburgh Academy.

Leonard Horner began to attend classes at the University of Edinburgh at the age of 14. He studied Moral Philosophy under Professor Dugald Stewart (whom he greatly admired and whose children became close friends of the Horners), Mathematics under John Playfair (another long-standing friend), and later Chemistry under Dr Hope through whom he first discovered Geology which was to be a life-long study. During this time Leonard and Francis wrote frequently to each other. Francis had set up a legal practice and embarked on a promising career as a Whig politician in London. In their letters they discussed Leonard's university studies in some detail as well as the public issues in which Francis was now involved. Leonard was always interested in questions of economic and fiscal policy and in his own study of political economy but he was also very anxious to pursue experimental science. On one occasion ${ }^{1}$ Francis advised him to concentrate on political economy while he could take advantage of the lectures in Edingburgh, since if he were to come to London he would find any number of science courses offered but no political economy. Leonard seems to have taken his advice. Francis clearly had a very important influence on his younger brother. Leonard was very attached to him and proud of his success. Francis' death in 1817 at the early

printed in 1890. This is a fascinating account of Horner's life and thought. Unfortunately it has only a scanty and inadequate index and is more concerned with Horner's private and scientific pursuits than with his public career. His period as Warden of London University is mentioned only very briefly and his work as Inspector of Factories barely touched on.

${ }^{1}$ Memoir, Vol. I, p. 5, 6 June 1803, F. H. to L. H. 
age of 39 shocked the whole Horner family and Leonard was particularly affected by the loss. ${ }^{1}$

Leonard Horner left University in 1803 at the age of 19 to go into partnership with his father. He moved to London that year partly to be near Francis and partly to manage the London branch of the family business. However, the linen trade was beginning to enter a state of decline and although the Horners remained relatively prosperous for some time yet the tide was against them. Sometime during this period - probably a few years after he married in 1806 - Leonard attempted to strike out on his own, with his family's full approval, as an underwriter in Lloyds Insurance Office. But he was never happy with the risks involved in this type of financial speculation, and in 1813 after some serious losses which his father seems to have redeemed for him $^{2}$ he gave up the post and returned to the family business in Edinburgh after ten years in London.

In remembering Horner as the longest serving of the early Factory Inspectors it is easy to forget that he had an equally long career as a businessman behind him when he entered the service of the Home Office. One might also note in passing that he always had a private income, though probably only a modest one after the decline of the family business, in addition to any salary he might earn. ${ }^{3}$ Without this his pursuit of geology might have been more difficult.

1 In the autumn of 1816 Leonard accompanied his brother on a journey to Italy which it was hoped would improve Francis' health. Francis died, however, on February 8th 1817 in Pisa, apparently from some form of tuberculosis. When Horner revisited Pisa as an old man in 1861 he wrote: "This place is associated in my mind with the greatest calamity of my life" (Quoted Memoir, Vol. I, p. 135). In 1843 he published a Memoir of his brother. A statue of Francis Horner now stands in Westminster Abbey.

2 Memoir, Vol. I, p. 24, 11 November 1813, and page 26, 10 November 1813.

3 As Secretary to the University of London he received $£ 1,200$ per annum, of which $£ 200$ was to cover the expenses of running a "gentleman's residence" in Central London. As Inspector of Factories his salary was $£ 1,000$ per annum out of which he had to pay his own travelling expenses. When Horner died in 1864 he left effects to the value of almost $£ 18,000$. At least $£ 12,000$ of this was invested capital which he left to his six daughters (£2,000 each). These sums are perhaps $1 / 10$ th of present-day values. It is clear that he was not a poor man. Yet he postponed his retirement as Inspector of Factories for two years or so until the age of 73 because he regarded the pension scheme as inadequate. When he finally retired he unsuccessfully petitioned the Home Office for an augmentation of his retirement allowance of $£ 550$ per annum on grounds of his past service. He may have been worried about providing for his two unmarried daughters but in view of his consistent caution about money throughout his life it is more likely to have been a reflection of his struggles in a declining trade, the businessman's dislike of converting working capital into income and perhaps an expression of Puritan thrift. 
Horner's 25 years as a linen merchant involved a great deal of hard work and much travelling both within Great Britain and in Europe. During these years he met and corresponded with economists, politicians (usually Whigs) lawyers, scientists of many kinds and a catholic collection of churchmen as well as family friends and mere business contacts. He never lost the intellectual and political interests which he had developed under his brother's influence as a boy and he remained a scholar, albeit a scholar with a bent to the practical, all his life.

In 1827 through his Scottish Whig connections Horner was invited to become Warden and Secretary of the newly created University of London. He stayed in this post for only four years and then after two years of travel and study in the Rhine valley he was appointed Inspector of Factories in 1833. His experience as Warden of London University is of sufficient interest to be described in a separate section and his career as Inspector of Factories will be discussed at some length below, but this is perhaps the appropriate point at which to give an account of his public activities and his private intellectual interests which, though they continued through his life, received their first stimuli in his early years in Edinburgh and their firm foundation during his years as a hard-working businessman.

\section{II}

INTELLECTUAL INFLUENCES, PRIVATE INTERESTS AND PUBLIC WORKS

From his childhood Leonard Horner was open to a number of important influences which shaped his values and his thought. He was a Scot, a Whig and a Protestant, and from all three traditions he learned to value independence and to feel a sense of public duty and the claims of conscience. He was also a product - perhaps the last ${ }^{1}$ - of the Scottish Enlightenment which had for some generations affected the uppermiddle-classes of Edinburgh through the University and the political cliques of the city. From the Enlightenment Horner inherited a splendid tradition of wide scholarship and the assumption that the chief end of learning was to pursue truth. Through his brother's côterie and his own study of political economy he absorbed a good deal from the Utilitarian school of thought. The principle of utility is a central concept in his writings on the factory question, and in other contexts too he always respected what was useful, practical and likely to improve the quality of life for any social group.

All these traditions ultimately affected Horner's work as Inspector of Factories but they found other expressions too in his private intel-

${ }^{1}$ I am indebted to H. L. Beales for this observation. 
lectual pursuits and the voluntary public service in which he engaged from an early age. The following section will attempt to outline the range of these interests and activities and to indicate some of the connecting threads which link them.

The most important of Horner's private pursuits was undoubtedly geology. About this time the new science attracted many gentlemen with a little spare money and the opportunity to take country walks: it was not yet a laboratory subject, and a small hammer for taking rock samples was adequate equipment. Horner was no dilettante however and he achieved a scientific reputation of some distinction. His interest in geology was serious both for the intellectual challenge it posed and for the practical value which its discoveries might have. For example, he was keenly interested in discussion at the Geological Society about Humphrey Davy's lamp ${ }^{1}$ for detecting fire-damp in mines. More importantly he was himself one of the initiators in 1835 of the Geological Survey of Great Britain, ${ }^{2}$ an enterprise which was as much concerned to chart the mineral wealth of the country as it was to pursue a disinterested intellectual task.

Horner joined the Geological Society of London in the second year of its existence, 1808, and was its Secretary 1810-14 and its President 1845-46 and again 1860-61. All his life he was an active student of geology and produced a number of publications of some importance. After his retirement as Inspector of Factories he devoted a good deal of his time to the affairs of the Geological Society and in his last years spent several hours each day reorganising its Museum and Library. His quality as a geologist can be judged by his election as Fellow of the Royal Society at the age of 28 in 1813. His Vice-Presidents at the Geological Society included such eminent geologists as the Rev. W. Buckland, FRS (Dean of Westminster), Robert Hutton, R.I. Murchison, FRS, and Professor Owen, FRS. His influence and his percipience are also illustrated by his patronage of two outstanding younger geologists, Charles (later Sir Charles) Lyell ${ }^{3}$ and Alexander (later Sir Alexander) Geikie for whom he virtually ensured the post of first Director of the Geological Survey. ${ }^{4}$

Geikie in an obituary notice described Horner as "ever ready to receive and sympathise with new developments of truth". ${ }^{5}$ Openmindedness and careful observation were the keynotes of his geological

${ }^{1}$ Memoir, Vol. I, p. 81, 10 November 1815, L. H. to Dr Marcet.

${ }^{2}$ Information supplied from the archives of the Geological Society by Dr W. Bishop, Department of Geology, Bedford College, University of London.

${ }^{3}$ Information from Dr Bishop, as above. See also p. 423

4 Information from Dr Bishop, as above.

5 Proceedings of the Royal Society, XIV, 1865, p. 5. 
work. His own researches, apart from one excursion into the field of archaeological geology, were all in the field of mineralogy. In an obituary address to the Geological Society Sir John Hamilton had high praise for his caution and avoidance of hasty generalisation. Horner's careful descriptions were an important part of the observational basis on which principles of classification were developed by the next generation of geologists such as Murchison and Sedgwick:

Horner the geologist was always concerned both to safeguard academic standards and to popularise interesting and useful knowledge. He believed that membership of learned societies should not be lightly awarded. For this reason he conducted a successful campaign in the Royal Society in 1846 to tighten up admission to membership ${ }^{1}$ and in the Geological Society he was always concerned about the intellectual calibre of office holders. ${ }^{2} \mathrm{He}$ also believed that the findings and discussions of these societies should be made available to the public. Accordingly during his first period as President of the Geological Society in 1845 he reformed and speeded up the publication of the Society's transactions. In his second Presidency in 1860-62 he "made strong efforts to render the meetings of the Society more popular and attractive to the general public by the admission of ladies to the meetings." 3 The experiment was disliked by many members of the society and unfortunately was not a success since "few ladies other than Lady Lyell and the Misses Horner attended regularly". The rule was reversed in 1863 after the end of Horner's Presidency and women were not admitted again to meetings until 1904.

His progressive views about women in science had led him into one controversy in the Geological Society: his open-mindedness to new scientific ideas led him into another. He was a friend of Charles Darwin and had been interested in his work for some years before the publication of The Origin of Species. In 1861 he attracted a great deal of comment by devoting his Presidential Address to the Geological Society ${ }^{5}$ to a review of the evidence for the antiquity of the world and the inadequacy of Archbishop Usher's Bible chronology of creation. Included in his review was an ingenious piece of research which he had carried out himself, an attempt to date ancient buildings in the Nile Valley by measuring the depth of sediment in the river. Though he was much criticised for this controversial use of his Presidency he received

1 Memoir, Vol. I, p. 98, 12 May 1846, and p. 89, 16 May 1856.

2 See, e.g., Memoir, Vol. I, p. 89, 14 March 1816, L. H. to Dr Marcet.

${ }^{3}$ Horace B. Woodward, The History of the Geological Society, London 1907, p. 242.

4 Woodward, op. cit., p. 242.

5 Journal of the Geological Society, 1861. 
appreciative letters not only from Darwin but from two churchmen, the Deans of Hereford and Westminster, ${ }^{1}$ and cautious but not hostile thanks from W. E. Gladstone and Archbishop Sumner of Canterbury to whom he had sent copies of his address. ${ }^{2}$

Perhaps Horner himself made the best summary of his general intellectual position when he wrote to his daughter with reference to another geological controversy: "I suppose it is a rare quality, the possession of that candour which would be as ready to admit a fact against as in favour of a preconceived opinion. I believe that the cultivation of such a frame of mind is as necessary in science as in politics or religion."3 Horner perhaps never quite achieved this ideal state of mind, yet by the standards of British society in his time he was extremely open-minded. He derived this quality not from a secular or sceptical viewpoint but from the traditional Protestant esteem for independence and rationality.

Protestantism was a deep and powerful influence in Horner's life. ${ }^{4}$ The following is a characteristic passage which gives the key to much of his personality and belief. In a letter to his wife written during one of his autumn tours of the Lancashire factories he wrote: "I was in a comfortable little fly and I read the first two books of 'The Paradise Lost' by the way; such majesty of diction is not to be found in any other work in our tongue." 5 Both the practice of employing usefully every minute of the day, even the journey between cotton mills, and the admiration for England's greatest Puritan are Horner's hallmarks. Thrift, hard work and a moderate asceticism were virtues to which he paid more than lip service. For example, he always rose between 5 and 6 a.m. just as the factory children had to, and used the time before breakfast for reading and writing; he would return to his private studies again at the end of his working day.

Horner equated true religion not with ritualism, authority or

1 Dr Richard Dawes, Dean of Hereford was an educational reformer with whom Horner had a good deal of correspondence. Arthur P. Stanley, then Dean of Westminster, became a distinguished ecclesiastical figure.

${ }^{2}$ Memoir, Vol. II, p. 303, 26 March and 1 April 1861.

${ }^{3}$ Memoir, Vol. II, p. 279, 15 November 1857, L. H. to his daughter Francis.

4 The Memoir does not make clear what the church of allegiance was - probably Scottish Presbyterian. His close acquaintances included many Anglican ecclesiastics however, and in one of his last letters he wrote of attending the "Free Christian Church" as if it were his normal practice. Memoir, II, p. 366. Cf. the argument of John Vincent in The Formation of the Liberal Party 1859-68, London 1966, about the importance of the connection - often apparently arbitrary - between Protestant sentiment and political causes in the ground swell of mid 19th century liberalism. Horner is an early but perfect example of this to set alongside Baines and Miall.

s Memoir, Vol. II, p. 64, 9 September 1843, L. H. to his wife. 
antique tradition but with intellectual honesty and serious thought on weighty matters. The following passage - one might call it an Enlightenment view of Sabbath-keeping - illustrates this view beautifully:

"(on Sunday) I did not go to church, but I read three sermons of Robert Hall, and a part of Cicero's disquisition on the immortality of the soul, in his Tusculan Questions, so I was not without my serious reflections on the day of rest. I had Madame de Stael's 'Allemagne' for another part of the day, and when candles came, I took the larger print of Humboldt ('Asie Centrale'); thus though there was profound silence, I was in good company all day, with very pleasing and profitable converse."1

In a real sense and in his own eyes it was a religious viewpoint which permeated Horner's thinking. Independence of mind and the disinterested search for truth in all its forms were the true object of both religion and science. Fundamental conflict between the two was therefore impossible. For this reason he never saw the theory of evolution as a threat to the essential truth of Christianity. His reaction to biblical criticism was similar. As soon as it appeared in England in 1863 he read Renan's Vie de Jésus and found it exciting that something like scientific method could be employed in this field: he felt it would rid Christianity of the mythical and ritual accretions imposed by the priests. He wrote of Renan's book: "I am not at all surprised at the fury of the priesthood, for their craft has not been more powerfully assailed for a long time. But pure Christianity ... will be more firmly rooted in the minds of all who exercise the reason God has given them."2

His letters are full of scathing condemnations of Roman Catholicism, Puseyism and the "priestcraft" - (a favourite word) - of both as enemies of truth and freedom. He was appalled by attempts to restore the Roman Catholic hierarchy and diocesan structure in England, ${ }^{3}$ yet he was a tolerant man in other respects. He supported Catholic Emancipation and wholly approved of religious toleration. What he feared and despised was the power of the priest or even the presbyter when it derived from custom or authority and not from freedom. In a letter to his daughter Susan he wrote:

"It is not because of the belief that I think the Roman Catholic the worst form of Christianity, because all or nearly all forms have

1 Memoir, Vol. II, p. 63, 9 September 1843, L. H. to his wife.

2 Memoir, Vol. II, p. 363, 12 December 1863, L. H. to his sister, Mrs Byrne.

${ }^{3}$ See, e.g., Memoir, Vol. II, p. 175, 27 December 1850, L. H. to his sister, Mrs Byrne.

4 See, e.g., Memoir, Vol. I, p. 243, 7 February 1829, Francis Jeffrey to L.H. 
some irrational dogmas, the Roman Catholic more than any others; my abhorrence of it rises from the audacious dominion the priests exercise over the minds and conduct of their subjects." 1

The journals he wrote on his European visits all contain commentaries on the politically stultifying effect of Catholicism on backward populations who had not yet learned to care for liberty and selfgovernment. He had for example great and utterly unrealistic hopes for the progress of Waldensian Protestantism in Italy. He wrote to his daughters in 1861: "The Roman Catholic faith hangs so loosely upon a large portion of the population of all ranks, that with the progress of freedom and education, as soon as an opportunity offers for dropping it with personal safety ... there will be a material change." 2 That nationalism, a liberating movement, could fail to be accompanied by Protestantism never occurred to him.

One should not assume from this one mistaken judgement that Horner was uninformed or unintelligent about political affairs. He was always deeply interested in politics and had a voracious appetite for political literature in which he included history, philosophy and biographies, as well as straight political commentary. As a committed Whig he was always anxious to draw practical lessons from what he read. One might illustrate this from almost any page of the Memoir, but the following is typical and provides a guide to Horner's views on any issue of government and foreign policy. On receiving his son-inlaw's (Chevalier Pertz) biography of Stein, which had attracted the favourable attention of the King of Prussia, Horner wrote to his daughter in Berlin that he hoped the King would "call to his aid Ministers such as Stein ... men who hold the same enlightened views of civil and religious liberty, whose thoughts are directed to the happiness and prosperity of the governed as Stein's so readily were."3

This quotation also shows the element of paternalism in Horner's political views. He never equated liberty with simple egalitarianism as did some of the Radicals, but always held the view that the good state needed both an enlightened and educated people and an elite who could guard the liberties of all: a combination characteristic of both Whig and Enlightenment thinking.

Horner was an active as well as an armchair politician, particularly in the period 1813 to 1827 . Lord Cockburn considered he was the moving spirit of the Whig côterie of Edinburgh at this time. For

1 Memoir, Vol. II, p. 258, 20 April 1856, L. H. to his daughter Susan.

2 Memoir, Vol. II, p. 323, 15 October 1861, Italian Journal to his daughters.

${ }^{3}$ Memoir, Vol. II, p. 252, 12 August 1855, L. H. to his daughter Leonora. 
example he organised the Fox Dinner in 1822 and in 1825 was asked to take the chair when the Whigs of Edinburgh gave a dinner in honour of Joseph Hume. ${ }^{1}$ His services to his native city at this period were very considerable. In 1816 he conducted a successful campaign to reform the administrative and medical service of Edinburgh Infirmary. ${ }^{2}$ This was an early example both of his imperiousness and of his dislike of inefficiency and corruption which he regarded as wasteful and unnecessary. In the 1820's he was involved in the foundation of two schools, the School of Arts and the Edinburgh Academy. In these schools one sees again the two objects which Horner also pursued in the Geological Society, the preservation of the highest academic standards for an elite and at the same time the extension of useful knowledge to humbler folk.

The Edinburgh Academy which opened in 1824 was the idea of Henry Cockburn, and Horner. It was designed for middle-class boys to remedy "the decline of classical education in Scotland."3 Horner and Cockburn thought that the one classical school in Edinburgh which was run by the (Tory) town council had lowered the standard of classical scholarship by offering it to a class of boys who could never make use of it. Horner always took a close interest in the development of the Academy and was for example very proud of Archie Tait, one of the Academy's early products who became Bishop of London in 1856 and Archbishop of Canterbury in 1868 after Horner's death. The other foundation, the Edinburgh School of Arts for the education of mechanics and artisans was started in 1822 entirely on Horner's initiative. ${ }^{4}$ It offered a wide range of courses but its emphasis was on applied science. The School of Arts - perhaps the first real mechanics' institute - was one of the most outstandingly successful institutions of its kind and its early reputation depended to a considerable extent on Horner's energetic management in its first years. It was later united with the Heriot Trust and is now most appropriately a part of the new Heriot-Watt University in Edinburgh.

Horner's concern for education was never superficial. This is shown by his continued and detailed concern for the two Edinburgh schools, his lifelong interest in proposals for educational reform and not least by the education he gave his own daughters. The policy of admitting women as observers at meetings of the Geological Society was no

${ }^{1}$ Lord Cockburn described Horner as "the most active and enlightened of our citizens, and with a singular talent for organisation". Memorials of His Time, Edinburgh 1874, p. 326.

2 Memoir, Vol. I, p. 141, 14 Dec. 1817, L. H. to Dr Marcet.

${ }^{3}$ Lord Cockburn, Memorials of his time, quoted Memoir, Vol. I, p. 212.

${ }^{4}$ Lord Cockburn, Memorials of his time, quoted Memoir, Vol. I, p. 196. 
isolated example of Horner's radicalism about the education of women. There is no record of his views on the Woman Question, which anyway did not become a burning public issue until quite late in his life - but his treatment of his daughters is sufficiently eloquent in itself.

The six Misses Horner were very emancipated for their time without being in the least indecorous. ${ }^{1}$ Their father educated them every bit as rigorously as if they had been boys ${ }^{2}$ and his letters show that he regarded them as his intellectual equals. Their own achievements were by no means negligible. All had more than a superficial knowledge of science and some had independent publications to their credit. Katherine Lyell, for example, published a Handbook of all the known Ferns in 1870. They were linguists and historians too. Frances translated Count Balbo's life of Dante into English; Susan translated and wrote a concluding chapter to Colletta's History of the kingdom of Naples; Leonora and Joanna translated a geological treatise, Lepsius' Letters from Egypt. They were all politically and socially literate and as concerned as their father for public issues - Frances for instance founded two schools on her husband's estate. And perhaps most interesting of all, the four who married seem to have chosen their own husbands, all of whom were distinguished and scholarly men. ${ }^{3}$

Horner's own erudition was quite formidable. His interest in science, politics and political economy has already been noted. In addition to the classical languages which he learned at school Horner taught himself French, German and Italian in order to read scientific, political and literary works and converse with scholars, politicians and businessmen on his travels in Europe. At the age of 77 to occupy his time and relieve his sorrow after his wife's death he translated Villari's biography of Savonarola; the scholarly and ascetic friar who defied the Pope and became a martyr to the Inquisition was very much to Horner's taste. Poetry and literature were a constant pleasure to him too. His letters to his wife and daughters were full of appreciative accounts of Scott and Charlotte Brontë, Dante and Schiller. His

1 It is interesting to note that Katharine Lyell employed the Women's Printing Society Ltd., to publish her Memoir of her father in 1890.

2 When his elder daughters were children he undertook a good deal of their education himself. In addition they had governesses - none seems to have been sent to school. Horner's only son died as a child.

${ }^{3}$ Mary married Charles later Sir Charles Lyell, geologist and university professor. Francis married Charles later Sir Charles James Fox Bunbury (Bart.), son of a Whig landed family with a scholarly tradition and himself a serious amateur botanist. Katherine married Captain, later Colonel Henry Lyell, younger brother of Charles. Leonora married Chevalier George Pertz of Berlin, bibliographer and historian of some distinction. 
tastes were serious but catholic and the only book he ever condemned was Tom Jones which he found too coarse for his liking. ${ }^{1}$

One might well think that such an erudite and yet practical man would have been a very appropriate administrative head of a new University. Yet Horner's four years as Warden of London University were the most harassing and least successful of his life.

\section{III}

\section{WARDEN OF THE UNIVERSITY OF LONDON, 1827 TO $1831^{2}$}

In May 1827 the Council of the newly formed University of London invited Horner to accept the post of Secretary of the University. The University was designed especially for the new middle-classes. Its moving force was a group of Scots, Dissenters and Jews with Henry Brougham as a figurehead. The Scottish Whigs were the most influential single group among the Proprietors and the early Council. They included a number of Horner's friends and acquaintances, notably Henry Hallam, John Wishaw, James Mill and Brougham himself. They followed Scottish and German models in establishing the lecture as the main teaching instrument and encouraging wide modern courses. From his appointment Horner was deeply involved with this group in drawing up broad, up-to-date syllabuses and general courses to include science, languages and even a social science before a narrower specialisation was possible. His achievements in this respect were by no means negligible but for the most part his experiences in Grower Street were less rewarding.

There were two main sources of trouble which would have made the job of any Secretary trying. The University was a joint stock company and this entailed first the total exclusion of the teaching staff (mere employees) from policy decisions and second their remuneration from the fees of such students as they had the power to attract to their

1 Memoir, Vol. II, p. 264, 30 November 1856, L. H. to his daughter Francis. 2 The fullest existing account of the University episode is $\mathbf{H}$. Hale Bellot, University College London 1826-1926, London 1929, esp. Ch. 6. This is based on original documents of University College, and is entirely accurate as to fact but emotionally biased against Horner. I also consulted the following: a) the Memoir, which contains a very brief and unrevealing account; b) F. G. Brook, The University of London 1820-1860, unpublished Ph.D. thesis London 1958; and c) three privately printed pamphlets: L. Horner, Letter to the Council of the University of London, 1st June 1830, London 1830; G. S. Pattison and others, Observations on a Letter addressed by Leonard Horner to the Council of the University, 1st June 1830, London 1830, and G. S. Pattison, Professor Pattison's statement of the facts of his connection with the University of London, London 1831. 
individual classes. For the first few years Council reluctantly agreed to various temporary guarantees of income of which McCulloch's ${ }^{1}$ $£ 400$ was the highest. It seems possible that the founders over-estimated the early public appeal of the University and miscalculated the likely income of a Professor. Brougham predicted $£ 1,200$ a year from fees to Professor Lardner ${ }^{2}$ but in fact the normal professorial income even with guarantees was more like $£ 300$, and some Professors seem to have been struggling to exist as "gentlemen" on as little as $£ 100$. Horner was unpopular both as financial officer exercising Council's niggardly policy and because his own salary was $£ 1,200$ a year. The provocative contrast was further heightened by the fact that while the Professoriat had no part in University government not only was Horner intimate and influential with Council and important Proprietors but he and Council took a view of the office of Warden as conferring "that authority over the Professors, which is usually vested in the Principal or Acting Head of other Academical Institutions". ${ }^{3}$

Horner seems sometimes to have been tactless and high-handed in exercising his powers both over petty administrative and financial matters and on larger issues such as academic appointments. $\mathrm{He}$ irritated the Professors by setting up beadles to record their students' attendance at lectures; he minutely supervised their laboratory expenditure and on one occasion he refused to set in motion the payment of a Professor's salary until he personally and not Council had received the correct form. Some of the Professors suspected that Horner had influenced Council in their appointment of two scientists, Professor Bell and Mr Bennett. Bell was appointed to take over the chair of Surgery when Granville Pattison was unwillingly transferred from that post to the Professorship of Anatomy; Bennett was appointed Pattison's demonstrator although Pattison had intended the post to go to his nephew. That Horner may have had a hand in these appointments is not intrinsically unlikely. Bell and Bennett were distinguished Edinburgh scholars. Moreover Horner was certainly exercising academic patronage about this time: in 1828 he was responsible for inviting Charles Lyell to the Chair of Mineralogy at King's College London. ${ }^{4}$

\section{Professor of Political Economy from Edinburgh.}

2 H. Hale Bellot, op. cit., p. 175.

${ }^{3}$ Letter from Horner to Lord Auckland, President of Council 1827. Quoted Memoir, Vol. I. p. 233, and in Horner's and Pattison's letters to Council, op. cit. - Information supplied from Archives of Geological Society by Dr W. Bishop, Dept artment of Geology, Bedford College, London. Lyell married Horner's eldest daughter, Mary, in 1832, but in 1828 there was no question of Horner's having foreseen this: he was genuinely surprised and delighted by news of their 
Horner's imperious manner and lack of tact certainly cannot have helped matters, yet by virtue of his office the Warden was almost bound to become the target of hostility however he acted, and there is no doubt that Horner was sometimes seriously provoked. The hostility between him and the Professors came into the open partly over an anonymous letter which he injudiciously wrote to a newspaper and partly on the question of Professor Pattison's incompetence. The anonymous letter, written under the pseudonym of "A Proprietor", was published in the Sun on April 22nd, 1829. It concerned the system of salary guarantees about which the Professors had been publicly complaining. In it Horner described the guarantee system perfectly accurately but emphasised that any guarantee of income was granted not of right but through Council's magnanimity. Moreover in the course of analysing the difficulties of attracting paying pupils he pointed out to the Professors that "their reputation (with the paying public) has yet to be earned." 1 The Professors were outraged when the authorship of the letter was revealed and even McCulloch complained on this count though he had no other criticisms of Horner.

So far as the second issue was concerned, Pattison had certainly neglected his academic duties and refused to teach the most modern theories of anatomy, ${ }^{2}$ a thing which was hardly likely to commend him to Horner who was himself a more adventurous scientist. Pattison was complained of several times both by students and colleagues, but he attributed this to malicious persecution contrived by Horner. There is no evidence to support this suspicion even though Horner was undoubtedly sympathetic to the complaining students ${ }^{3}$ and on friendly terms with Bell and Bennett, Pattison's more distinguished academic rivals in the University.

In April 1830 Pattison and eight other Professors complained to Council about Horner's conduct and asked that the office of Warden be abolished. Council investigated the matter and merely confirmed its support of Horner, although despite the hopes of Hallam and the six

engagement in 1831. Memoir, Vol. I, p. 251, 20 July 1831, L. H. to his daughter Mary.

1 Quoted in both Horner's and Pattison's letters to Council, op. cit. Most of the professors were very young incidentally.

${ }^{2} \mathrm{He}$ admitted both in his letter to Council but claimed there were extenuating circumstances.

${ }^{3}$ He may have partly been influenced by the fact that his brother Francis and some of his friends (including Brougham) had been threatened with dismissal from the University of Edinburgh in their boyhood by a Professor Hume who disapproved of their political views. See "Francis and Leonard Horner" by Mary Lyell, privately printed, Edinburgh n.d. 
Professors who supported Horner, none of the complainants was dismissed. ${ }^{1}$ A year of skirmishing followed, the high point of which was a near-riot which occurred when Horner allowed a Mr Thomson, a student who had proviously been dismissed for putting in a complaint against Pattison, to address Pattison's students before a lecture: the students prevented Pattison from lecturing for over a month. After this Council could not ignore any longer the persistent demands of the academic staff for constitutional reforms. First, however, Horner resigned, largely on grounds of ill health; four years of chronic indigestion had undermined his resilience. Pattison was dismissed, and on the recommendation of a constitutional commission the Professoriat was given a part in University government and the Warden was replaced by a Secretary with restricted powers and a salary of $£ 200$, one sixth that of Horner.

The limits of administrative power in Universities and the role of teachers and students in policy making are still live issues. In this case the conflict between Warden and Professors was almost certainly exacerbated by the fact that however much his opponents tried to represent him as an ignorant businessman ${ }^{2}$ Horner was in fact a scholar in his own right, well able to evaluate the competence of Professors of Science and advise Council on academic matters.

The University controversy also shows the less attractive and in this case the less fruitful aspect of Horner's independent spirit. To him independence and authority were inseparable: limited or ambiguous authority he found uncomfortable and unprofitable. Later as Inspector of Factories he battled just as autocratically with the Home Office and his colleagues as well as with recalcitrant factory occupiers, but this time he produced not deadlock but the firm administration of an unpopular law and often much-needed innovation to remove the ambiguities and loopholes in it. But this is to anticipate.

After his resignation as Warden of London University Horner travelled in Europe with his family to regain his health. On arriving in Bonn where he subsequently lived for two years he wrote in his journal: "what a place this is! It exceeds all my anticipations - what delicious peacefulness, and no University." 3 The ex-administrator and businessman turned private scholar and spent two sabbatical years studying the geology of the Rhineland. His father had died in 1829 and so he was able to live on his inheritance without undue anxiety to find a salaried post immediately. However in April 1833, again through Whig con-

1 Memoir, Vol. I, p. 247, 4 June 1830, Hallam to L. H.

2 See quotations to this effect from Thomas Murray in Bellot, op. cit., p. 195.

${ }^{8}$ Memoir, Vol. I, p. 255, 16 August 1831, L. H. to Charles Lyell. 
nections, he was appointed to a "Commission to enquire into the employment of children in factories", and in November 1833 after the Factory Act of August that year he was offered a vacant post as one of the four Inspectors of Factories by Francis Jeffrey, Lord Advocate of Scotland and an old Edinburgh friend of Horner's in whose patronage Lord Melbourne had placed the post. For almost 26 years until his retirement in 1859 Horner remained Inspector of Factories, first for Scotland and then from 1836 for the Lancashire district.

\section{IV}

\section{INSPECTOR OF FACTORIES 1833-1859}

Much of Horner's work in the Factory Department has been documented elsewhere in more detail than it is possible to give here. ${ }^{1}$ However, all the existing accounts are embedded in general discussions of the early English Factory Acts. The following outline will therefore be particularly concerned with the unique features of Horner's role.

The Act under which he was appointed in 1833 is usually regarded as the first effective Factory Act to be passed by the British Parliament. It concerned only the textile trades and briefly it forbade the employment of children under nine years of age, restricted the hours of work for children between nine and thirteen years to 48 a week and required that such children should attend school for an average of two hours a day. Young persons between 13 and 18 years of age were restricted to 12 hours work a day and forbidden to work between 8.30 p.m. and 5.30 a.m. There were other clauses requiring some minimal hygiene and ventilation in the workplace, the fencing of dangerous machinery and certain regular holidays and meal hours for protected persons. In 1844 the provisions were tightened in a number of ways; notably childrens' working hours were reduced to $6 \frac{1}{2}$ per day and women were given the same protection as young persons. The Act of 1847 further restricted the hours of women and young persons to ten a day or 58 in a week. The Ten Hour Act was finally rendered enforceable in 1853 by the introduction of the Normal Day, that is the requirement that all the protected persons in any factory should be employed between the same twelve hours, 6 a.m. to 6 p.m. or 7 a.m. to 7 p.m.

The major innovation of Althorp's Act of 1833 was the system of Inspection to enforce the new requirements. The first Inspectors were given unprecedented powers to make regulations and even to act as

1 Notably in M. W. Thomas, The Early Factory Legislation, Leigh-on-Sea 1948, a very thorough analysis of the administrative as well as the legislative history of the early Factory Acts. See also J. T. Ward, The Factory Movement 1830-1855, London 1962. 
magistrates to enforce penalties on the spot when they detected a breach of the Act. These powers were gradually curtailed, sometimes at the request of the Inspectors themselves. The methods of enforcement which the Inspectors evolved in the early years were quickly codified into a set of regulations which were subsequently built into the 1844 Act. Their powers to act as magistrates were removed at the same time, although they could still summon witnesses to appear before the bench with whom they laid information of breaches of the law.

There is no evidence, apart from his general interest in political economy, that Horner had been particularly concerned about factory conditions until he became a member of the Factory Commission. Yet immediately he was appointed Inspector he threw all his energies into his new work. He was undoubtedly the most active and uncompromising of the early Inspectors, although Saunders often ran him close in this respect. Certainly he is the best-remembered, partly because of his long service ${ }^{1}$ and partly because his district was the centre of the textile trade, the first industry to be regulated and thus the natural focus of controversy and innovation. Lancashire remained the most important district until after his retirement since most of the extending Acts which brought the rest of manufacturing industry under inspection date from the 1860's. The Minutes of the meetings of the four Inspectors $^{2}$ make it clear that from very soon after his appointment until the end of his career it was normal for each Home Secretary to consult Horner in advance of his colleagues whenever legislation was contemplated or a controversy was in progress; for example, he was the only Inspector to be appointed a member of the Children's Employment Commission 1840-1842. This cannot entirely be explained by the fact that Horner was the social equal of his Ministers, ${ }^{3}$ because the same was true of all the early Inspectors. It can only mean that he was in effect, if not in name, the leading Inspector. As early as $1842 \mathrm{Sir}$ James Graham, an experienced and cautious Home Secretary is known to have referred to Horner as "the Inspector-General of Factories". Yet he was emphatically not the official overlord of the other three.

1 Of the other three Inspectors appointed in 1833, Howell died in 1858, Saunders died in 1852, and Rickards resigned through ill-health in 1836 and was replaced by Stuart who served until his death in 1849 .

2 Manuscript minutes were kept 1833-1867; they are now in the Public Record Office, London, LAB 15. The author consulted these and other manuscript data, mainly letterbooks (HO 87), for a Ph.D. thesis in progress on "Factory Legislation and Administration 1847-1878".

3 Palmerston, for example, was an old Edinburgh acquaintance of Horner's.

- Letter from Graham to the Bishop of London dated 27 December 1842. From C. S. Parker, Life and Letters of Sir James Graham, London 1907, Vol. I, p. 343, quoted Thomas, op. cit., p. 206. 
The Inspectors guarded their legal autonomy fiercely and opposed some tentative suggestions for administrative centralisation which were canvassed around Westminster in the early 1840's. Horner's preeminence was undoubtedly noticed if not always approved by his colleagues. Stuart, the lax and possibly corrupt Inspector for Scotland with whom he had a long professional feud seems to have resented even a fortuitous symbol of Horner's importance. At a meeting of the Inspectors in $1848^{1}$ Stuart proposed a resolution to alter the "sittings" which had previously been allocated alphabetically - Horner therefore automatically taking seat No 1 . Lots were drawn and Horner took No 3 while Stuart drew No 1.

Until 1878 each Inspector remained sole administrative head of his own district, responsible only to the Home Secretary. The 1876 Royal Commission on the Factory Acts was highly critical of this structure which had produced administrative chaos during the 1860's and '70's while the two remaining Inspectors, Baker and Redgrave engaged in a bitter personal rivalry for ascendency in the Department. It seems not unlikely that the apparently unworkable structure of multiple and independent Inspectorships was retained for so long partly because Horner as unacknowledged "Chief Inspector" had worked the system effectively for a quarter of a century and thus postponed the need for open reform. ${ }^{2}$

The characteristics and achievements of Horner's career as Inspector of Factories can be briefly summarised here, and the rationale of his approval of government intervention in the economy will be treated more fully in the following section. He was an experienced businessman himself and in no sense hostile to the rational desire of the textile masters to maximise their profits. But he was firmly convinced of the necessity and ultimately of the profitability of good working conditions and of education for the masses. He always believed that manufacturers could and should be persuaded to take his own view of the matter and maintained that the largest and most enlightened of them needed no persuasion. ${ }^{3}$ When he first took up his post as Inspector he assumed the goodwill and co-operation of the majority of manufacturers but was soon disillusioned. Although from the late 1840's the principle of the Factory Act found widening approval among the textile masters, especially those with large establishments, in 1833 the majority felt

1 Minutes for 15 January 1848, LAB 15, Vol. 2.

2 The Royal Commission of 1876 recommended the appointment of a Chief Inspector. Redgrave took the post when Baker retired in 1878 .

s This is one of his major arguments in, e.g., On the Employment of Children in Factories, London 1840, a comparative review of factory legislation in Europe. See also Section $\mathrm{V}$ below. 
either hostile or ambivalent towards the Act. Threats, prosecutions and fines were therefore necessary as well as gentlemen's agreements and sympathetic warnings if hours and conditions of work were to be kept within the new legal limits in even a portion of the establishments officially under inspection.

Horner attempted to administer the law fairly and rigorously but from the beginning he, quite as much as the other Inspectors established an informal principle of minimal prosecution. ${ }^{1} \mathrm{He}$ freely admitted that he always dealt with certain offences by exerting personal influence and exacting promises ${ }^{2}$ - those relating to certification of age or the posting of documents for instance, offences either trivial in themselves or difficult to prove. He was more inclined to prosecute for offences concerning the length of the working day, though even here he only had resort to the courts either when it was clear that personal influence would bear no fruit or where he had found his trust misplaced. This reluctance to prosecute is not entirely attributable to a sense of identity with the manufacturing class $^{3}$ or to a conviction that persuasion is intrinsically preferable to coercion, and it certainly cannot be put down to lack of courage. In part it was a response to the inevitable play of pressures and counterpressures to which any legislator or administrator is subject when he needs to maintain working relations of some kind with groups whose interests pull in diverse directions. Important too were the ambiguities in the law which manufacturers in the guise of magistrates could exploit. They could nullify the intentions of the Act and make fools of the Inspectors by returning not-guilty verdicts on a technicality, inflicting derisory fines or ignoring the blatant intimidation of witnesses dependent on the accused for employment and livelihood. It seems not unlikely that Horner would have been prepared to use legal sanctions more often had he been working within an administrively watertight law instead of one riddled with escape holes."

One of Horner's major objectives throughout his term of office was precisely to stop the escape holes and render the law administratively feasible. Here he played an innovatory role almost certainly more

1 The whole subject of offences under the Factory Act as delinquency is treated in a D. Phil. thesis in progress, "The Enforcement of Factory Legislation: a study in the enforcement of law related to white collar crime", by W. O. Carson, Department of Sociology, Bedford College, London.

2 See, e.g., his official Report for the period ending 30th September 1843.

3 Although there is no doubt he did feel such an affinity. He made a practice of dining or breakfasting with the major manufacturers in his district when he was on his tours of Inspection and sometimes stayed overnight in their houses.

- These escape clauses were often written into a Bill quite deliberately during the course of its passage through Parliament in response to pressure from interested parties. 
crucial than the efforts of the Parliamentary champions of factory legislation whom he and his colleagues educated and informed. He used every means open to him to press his opinion on the public, on Parliament and in particular on the Home Office that this or that change or extension to the Act was necessary if the law was to be made enforceable. He submitted draft Bills to the Home Secretary ${ }^{1}$ whether or not he was asked to do so; he wrote letters and attended meetings and deputations of masters, operatives and politicians. Despite warnings and against an early-established rule of the Home Office he persistently used his official Reports to document controversial issues. He was frequently required to revise his Reports ${ }^{2}$ and refused to do so on at least one occasion. ${ }^{3}$ This happened in 1856 when he had stated in his Report that certain magistrates and manufacturers involved in recent unsuccessful prosecutions were deliberately flouting the intention if not the rather ambiguous letter of the law relating to the prevention of accidents machinery. He also insisted on defending himself publicly against the charge brought by some aggrieved manufacturers that he was administering the law in a partial and malicious spirit in attempting to enforce the fencing laws. This incident was part of af long and mainly successful campaign in which he and the other Inspectors were involved throughout Horner's whole term of office to make the proper fencing of dangerous machinery genuinely compulsory. ${ }^{4}$ The second famous campaign in which Horner took a major role was aimed at preventing the "false relay" system ${ }^{5}$ a method of shift working which made it impossible for an Inspector to tell with any certainty how long a set of children had been working and therefore difficult to prosecute employers for overworking them. The act of 1853 finally put an end to the "false relay" system.

As well as campaigns to change the law he used his administrative powers to eliminate ambiguities wherever possible. A scientist and a pragmatist he experimented with ways of determining the age of a child seeking employment by using objective measures such as height or the state of the teeth so that he need not rely exclusively on the subjective assessments of certifying surgeons or questionable baptismal certificates. Indeed even after the 1837 Registration Act became effective, and reliable birth certificates were available Horner continued to

1 See, e.g., Minutes of the Inspectors' Meetings for September 1853, LAB 15, Vol. 2 .

2 See, e.g., Minutes of the Inspector's Meetings, 22 January 1848 and 10 December 1851, LAB 15, Vol. 2.

${ }^{3}$ Inspectors' Letter Books, 12 February 1856, HO 87, Vol. 3.

"See Thomas, op. cit., Ch. 15: the "mill-gearing" and "horizontal shafts" controversies.

5 See Thomas, op. cit., Ch. 18. 
insist, probably quite illegitimately, that his Certifying Surgeons should still use the criteria of a child's physical strength and appearance in granting certificates and should only accept documentary proof of age in disputed cases. ${ }^{1}$ This was only one of the many instances in which Horner behaved as if the Inspectors had shed none of their original powers. There were occasions when he clearly regretted the loss of the magisterial function. In 1850, for example, in the course of the fencing controversy he angrily but vainly demanded that Home Secretary Grey should condemn as illegal the decision of a certain bench of magistrates who had refused to convict for failure to fence high transverse shafts. ${ }^{2}$

His paternalistic autocracy, so disastrous in the University, was a persistent feature of his Inspectorship. He spent as much time as he could manage on personal visits to factories and close oversight of his Sub-Inspectors. He left few decisions of any importance to his subordinates - he and not the Sub-Inspectors, for instance, decided when to prosecute. On one occasion he greatly angered the Home Secretary by taking it upon himself to demand the resignation of a corrupt SubInspector rather than handing the matter over to his Home Office superior. ${ }^{3}$ This reluctance to delegate authority was a pattern common to all the early Inspectors and it ultimately produced the frustration and inefficiency criticised by the Royal Commission of 1876 . In the early years of the Factory Department it was inevitable and had probably been intended that the Inspectors should see to it personally that the law was enforced but as the Act was extended to all manufacturing industry and a small army of Sub-Inspectors was recruited ${ }^{4}$ so the Inspectors needed to become co-ordinating administrators. Horner is firmly placed in the earlier tradition which might best be called Palmerstonian - of being a passionate innovator, a jack-of-alltrades and an autocratic power unto himself rather than a career administrator in a London office. The transition to the latter only came with Redgrave, and one cannot help but feel that a Horner was infinitely more effective than a Redgrave would have been in the foundation years of the Factory Department. ${ }^{5}$

1 See, e.g., Horner's Report for the half year ended 31 October 1852.

2 Inspector's Letter Books, 4 March 1850, HO 87, Vol. 2.

${ }^{3}$ Inspectors' Letter Books, 15 and 23 June 1859, HO 87, Vol. 4.

4 Though there were never enough of them: eight Sub-Inspectors in 1833, 15 in 1845,20 in 1864,35 in 1868 and 55 in 1878.

5 The contrast would be mirrored in many government departments: a first generation of upper-middle class innovators followed by a second and subsequent generations of rather lower-status recruits who approximate more closely the ideal of impersonal, bureaucratic behaviour which is the modern stereotype of the civil servant. 
One of the most valuable aspects of Horner's Inspectorship was his work as an educator and populariser. In his official Reports and his other published works he was always concerned to inform and educate public opinion. Very soon after his appointment as Inspector he produced an explanatory pamphlet The Factories' Regulation Act Explained ${ }^{1}$ which was both informative and persuasive. His longer comparative analysis of factory legislation in Europe, ${ }^{2}$ his open letter on the Factory Act to Nassau Senior ${ }^{3}$ and his translation of and introduction to Victor Cousin's treatise On the state of Education in Holland ${ }^{4}$ all had the same purpose. He insisted on the importance of providing good communications for everyone involved in the Factory Act, ${ }^{5}$ and put a great deal of effort into making as clear as possible the letters of explanation which he sent out to all mill occupiers after any new Act. He required all notices under the Act to be as clear and simple as possible and to be hung in a place convenient and accessible to the workpeople. One of the many occasions on which he challenged Home Office tradition was his attempt in 1850 to get the legally approved abstract of the Act put into language which the operatives would immediately understand. Why not, he suggested, have selected abstracts of only the clauses relevant for particular establishment, and with the crucial clauses underlined or in larger type? The Law Officers of the Crown would not agree to this and Horner was overruled, ${ }^{6}$ but the attempt to clarify and simplify was typical. Interestingly enough the 1876 Royal Commission recommended the use of just such simplified extracts in conjunction with the legally approved abstracts of the Act.

There is no record of Horner advocating total state provision of schools for the poorer classes, and indeed his own efforts in Edinburgh indicate that he thought some private local provision was both possible and desirable. But there is no doubt that he was passionately convinced that the working classes ought to be educated. He entirely approved of government initiative in providing factory schools and subsidising them from the fines inflicted under the Factory Act. None of the early

${ }^{1}$ L. Horner, The Factories' Regulation Act explained with some remarks on its origin, nature and trend, Glasgow 1834.

${ }^{2}$ L. Horner, On the Employment of Children in Factories etc., London 1840.

${ }^{3}$ Letter from Mr Horner to Mr Senior in Letters on the Factory Act, by Nassau Senior, London 1837.

${ }^{4}$ On the State of Education in Holland, by V. Cousin, translated and with an introduction by L. Horner, London 1838 .

${ }^{5}$ He concentrated more on improving communications with masters and workers than with his own Sub-Inspectors however: he treated the latter as subordinates rather than partners. See above p. 432.

' Minutes of Inspectors' Meeting, 16 July 1850, LAB 15, Vol. 2. 
Inspectors took such minute care as Horner did in the allocation of the penalty fund to the schools in his district. He did not merely suggest general grants for books and equipment but sometimes specified the precise books he thought a school should have. ${ }^{1}$ There are some pleasant illustrations of his liberal views on education: one is a grant of $£ .50$ for "terrestral globes" 2 and the other an even more unexpected grant of $£ 10$ to Manchester Normal School "for the cultivation of Music". ${ }^{3}$ Much of his research as an Inspector was concerned to find the level of literacy $y^{4}$ of the population and the adequacy of the schools in his district. ${ }^{5}$ Moreover he was ruthless in refusing to license teachers whom he regarded as inadequate. There is little doubt that a good deal of his concern to limit the hours of work of the factory children stemmed from his conviction that this was a pre-requisite of their adequate education.

The success of the Factory Act owed a great deal to Horner's intelligence, honesty and indeed to his ruthlessness.

His work was appreciated by the younger Inspectors who paid him appropriate homage on his retirement. ${ }^{6}$ But a tribute from the Lancashire operatives on the same occasion pleased Horner much more. ${ }^{7}$ After his death Thomas Maudsley and William Leigh on behalf of the Operative Spinners of Lancashire sent a Memorial to the Misses Horner in which they wrote of Horner:

"His impartiality in the administration of the laws made for the protection of our wives and children, and his firmness in their vindication, have long commanded our esteem, and of which while we live we shall cherish a grateful remembrance."8

\section{POLITICAL ECONOMY AND FACTORY LEGISLATION}

Horner's published works on political economy all date from his 1 E.g., Inspectors' Letter Books, 14 February 1853 and 17 February 1858, HO 87, Vol. 3 and Vol. 4 respectively.

2 Inspectors' Letter Books, 17 December 1853, HO 87, Vol. 3.

3 Inspectors' Letter Books, 9 November 1849, HO 87, Vol. 2.

4 See, e.g., his detailed review of schools in his district in his Report dated April 1851.

5 See, e.g., the investigation into literacy among 2,000 Manchester factory children in Introduction to Cousin, op. cit.

${ }^{6}$ Memoir, Vol. II, p. 291. Not all the Inspectors were so popular with the operatives. Stuart was disliked (see Thomas, op. cit., p. 258), and Redgrave was mistrusted as unwilling to prosecute and over-appreciative of the employers' viewpoint. (See comment by Mr Green, Birmingham Trades' Council, Manuscript Minutes of Trades Union Council.)

7 Memoir, Vol. II, p. 291, 16 Sept. 1860, L. H. to Lady Bunbury.

${ }^{8}$ Quoted Memoir, Vol. II, p. 374. 
period as Inspector of Factories but there is no reason to doubt that his general approval of government intervention in this sphere was already well established in 1833 - he would scarcely have accepted the Inspectorship otherwise. Moreover Francis Horner was a notable exponent of factory legislation to protect women and children. It is important to note that the Horners were not renegades among students of political economy in taking this attitude. The object of this last section is to set Horner's views briefly in the context of those of the classical economists.

Professor Brebner ${ }^{1}$ first showed in his important critique of Dicey that the so-called "era of laissez-faire" was in fact a period of unparallelled growth in government functions. The intellectual justification for this expansion of the state apparatus was provided by the classical economists, particularly the Benthamites among them. The popular assumption that the classical economists preached simple theology of "laissez-faire" is a misconception if by "laissez-faire" one understands a total objection to government involvement in the economy. From Adam Smith onwards the classical economists argued vigorously that the free market could only be a conscious creation of positive law. Their theoretical ideal of perfect competition needed a strong central government first to break the aristocratic mercantile system of monopoly and privilege, and then to guard the free market from social and economic developments which might distort it. In short political economy was the intellectual facet of the attack which the new industrial middle classes were making on the political and economic hegemony of the landed aristocracy. "Laissez-faire" was one of their major weapons. As J. S. Mill put it, the principle of laissez-faire had work to perform "of a destroying kind" ${ }^{2}$ its major campaign was the Corn Law agitation.

While the classical economists were unanimous in the view that governments had legitimate destructive functions they were much more divided about the nature and extent of desirable state initiative of a positive kind. Among them the utilitarians were most in favour of wide-ranging government action while the liberal individualists were deeply suspicious of even "mild collectivist" 3 tendencies in the new

I J. B. Brebner, "Laissez-faire and State Intervention in Nineteenth Century Britain", in: The Tasks of Economic History, Supplement VIII to Journal of Economic History, 1948.

${ }^{2} \mathrm{~J}$. S. Mill, quoted in Lord Robbins, The Theory of Economic Policy in English Classical Political Economy, London 1952, p. 44.

3 The phrase "mild collectivism" was used of the utilitarians by "the Spectator". See David Roberts, Victorian Origins of the British Welfare State, New Haven 1960 , for this and for documentation of the argument in the following paragraphs. 
science. An uneasy tension between individualism and collectivism thus characterised political economy in the early 19th century. Until the 1830's the potential conflict remained submerged while the two wings of the movement worked together in attacking the mercantilist system. However, once their crucial victory had been won in the repeal of the Corn Laws fundamental differences became ever more clearly defined. In political terms both wings had been commonly known as Radicals but by the 1840's no one was in any danger of confusing individualistic Radicals of the school of Cobden and Bright with their Benthamite confrères, the Philosophic Radicals such as J. S. Mill. The latter group approved and indeed largely engineered such legislation as the Poor Law, the Public Health Acts, the Lunacy Commission, the Registration of Births and Deaths, the Ecclesiastical Commission and the Factory and Mines Acts. The liberal individualists opposed most of these measures. This late, Manchesterschool version of political economy gradually attenuated the classical insistence on the positive role of the state and in the 1830's and '40's condemned factory legislation and inspection in particular as misguided, mischievous sentimentalism and false philanthropy.

Even some of the utilitarians were hesitant in their attitude to factory legislation. David Roberts ${ }^{1}$ has argued persuasively that the Benthamites were much more certain of the utility of social legislation which indirectly oiled the wheels of capitalism than of measures which brought government directly into industry itself. They were certainly unhappy about suggestions that government should intervene in labour contracts between free, responsible adults, ${ }^{2}$ they were divided over the issue of legalising trade unions, ${ }^{3}$ and at least in the early years of the Factory Act they were very uneasy about restricting the moving power of expensive capital equipment. Yet in general they advocated any legislation which would improve the physical and intellectual quality of the labour force and prevent civil disruption. A problem arose for them only when the principle of liberty and that of social utility seemed to pull in different directions, or where economic profitability and social necessity seemed to conflict.

Leonard Horner was squarely within the utilitarian rather than the liberal individualists school of political economy. The principle of liberty was important to him but he was also part of a paternalistic

1 D. Roberts, op. cit.

2 For this reason a number of them who supported the emancipation of women, notably J. S. Mill and Henry Fawcett, opposed the protection of women in factories.

${ }^{3}$ Both legalisation and repression of trade unions actively involved the state however. 
Whig tradition which coalesced very easily with the collectivist aspect of utilitarian thinking. His early views exemplify the tensions within the Benthamite position but during the course of his Inspectorship he became ever more firmly convinced that social utility and economic profitability would both be best served by the extension and tighteningup of the Factory Act. The development of his views shows Horner employing the same intellectual processes as he used in his study of natural science, notably careful observation and a willingness to modify even cherished theories in the light of new facts.

Almost the only reference in Horner's Memoir to his views on political economy is an early letter which he wrote to Dr Marcet, a scientific colleague, congratulating him on the publication of his wife's Conversations on Political Economy. Mrs Marcet was one of the "popular priestesses" 1 who wrote little volumes of fables illustrating the principles of political economy. Like her better known rival Harriet Martineau she simplified the subject to the point of excluding entirely the classical teaching about the positive role of government. She had little for the working classes but hard sayings and advice not to try to push against the grain of capitalism by strikes and combinations. Yet Horner had nothing but praise for Mrs Marcet's work. However, the following passage from his letter to Dr Marcet may help to set his approval in its proper perspective:

"Mr W. Haldimand cannot do a greater service to his country than by getting each of his brother directors (merchant bankers) to study this treatise; and if Prevost can effect the same purpose at Lloyds, it will change the whole character of the merchants of London, which I suppose never stood more in need of improvement."2

This surely was political economy teaching the old mercantilist establishment the profitability of the free market.

Horner's most celebrated exposition of his views on the relationship between political economy and factory legislation was his open letter on the factory Acts to Nassau Senior which was published in 1837. ${ }^{3}$ Senior, a political economist more inclined to extreme individualism than Horner, had written a series of letters to Poulett Thomson, President of the Board of Trade, attacking the Factory Act and in

1 A phrase used by an anonymous reviewer of Mrs Marcet and Harriet Martineau in the Edinburgh Review, 1833. For an account of the popularisers of political economy see R. K. Webb, The British Working Class Reader, London 1958, and R. K. Webb, Harriet Martineau: A Radical Victorian, London 1960.

2 Memoir, Vol. I, p. 98, 1 October 1816, L. H. to Dr Marcet.

${ }^{3}$ In N. Senior, op. cit. 
particular the "inquisitorial" system of inspection. The core of Senior's economic argument was his famous contention that the whole of the profit in cotton manufacture was made in the last hour of the working day. He arrived at this conclusion by some simple but misleading arithmetic based on the incontrovertible fact that the cotton industry was very heavily mechanised. Because of its unusually high capital costs the industry needed to run its machinery for as close on 24 hours a day as the necessities of cleaning and maintenance would allow. To limit the working day would therefore be fatal to cotton production.

Horner, who had been Inspector in Lancashire for only a year at this time, wrote a vigorous reply to Senior much of which concerned details of the administration of the Act which are of only peripheral interest for the present purpose. His economic justification of the Factory Act was already quite clearly articulated. He argued firstly that children were not free agents and therefore needed state protection not merely in textiles but in every industry in which they were employed. Second$l y$, he believed that better working conditions, a modest reduction in the hours of labour and the education of the working classes would improve industrial relations and increase output. Thirdly, he pointed out that the best employers, the Gregs, the Ashworths, the Ashtons and their like, had already discovered the economy of good conditions: the law was not, as Senior claimed, designed to irritate and harass them but to bring into line the "immoral" and "unscrupulous" entrepreneurs who either did not see or did not care that in making money for themselves they were in the long run causing the depletion and degeneration of the labour force, which was a major part of the nation's capital resources. While Horner's argument was by no means devoid of humane feelings - like Mill he could be passionate about human exploitation and injustice - its characteristic Benthamite feature was an insistence on the social and economic utility of the Factory Act. The following passages give something of the tone as well as the content of his letter.

"It was proved beyond dispute (by the Factory Inquiry) that a large number of children, not free agents... were employed for a greater number of hours in the day than was consistent either with their having a fair chance of growing up in full health and strength - the working man's capital - or with an opportunity of receiving a suitable education. ... Independently of all higher considerations, and to put the necessity of properly educating the children of the working classes on its lowest footing, it is loudly called for, as a matter of police, to prevent a multitude of immoral and vicious beings, the offspring of ignorance, from growing up around us, to be a pest and nuisance to society; it is necessary in order to 
render the great body of the working classes governable by reason; and it is prudent to educate them, for the purpose of developing and cultivating their natural faculties, and of thereby adding to the productive powers of the country."1

And again:

"If the restrictions do cause a reduction in some degree of present profit, by raising the wages of children, is there not the most wellgrounded reason to expect that that outlay will, in the end, return with interest, by their having a more moral and intelligent set of work-people, who will be more regular in their attendance, will take better care of the machinery and be less apt to be misled into strikes; and that thus there will be less interruption to the productive powers of the fixed capital, the great point to be aimed at, as you so clearly demonstrate."2

The same argument appears in all Horner's published works on the Factory Act and was frequently repeated in his official Reports. An important feature of his view is his insistence that he was not calling for the suspension of the laws of political economy in the interests of humanitarianism, but that good political economy required the intervention of the state on behalf of the factory children.

In his treatise On the Employment of Children in Factories (1840) he put it this way:

"If the father has his natural rights, so has the child; and if the father robs him of this, the State must become his guardian and restore them to him...

...It appears to me that the interposition of the legislature on behalf of children is justified by the most cold and severe principles of political economy; and the alleged interference with parental authority by such legislation is a mere sophism.

The wealth of the country surely depends, in no inconsiderable degree, on people who are engaged in works of industry being capable of performing the greatest amount of labour in a given time without impairing their health; for it will cost a great deal less to maintain, in food, clothes and lodging two strong healthy men employed to perform a piece of work, than would be required if we had to employ three men to do the same work because of their inferior muscular powers. To cultivate the intelligence, and

1 In N. Senior, op. cit., p. 30.

${ }^{2}$ In N. Senior, op. cit., p. 31. 
increase the probability of useful inventions by improving the natural faculties of the working classes, must also be considered a source of national wealth...

... No one doubts that a large proportion of those deluded people who followed the Chartist leaders were betrayed into acts of violence and lawless outrage more from their deplorable ignorance than from any other cause."1

Like J.S. Mill, Horner believed that the principle of "laissez-faire" was misunderstood by the extreme individualists who merely used it as an incantation against state initiative. The following passages all make this point.

"It must be abundantly clear by this time that the maxim 'laissez nous faire' however true in matters of trade, is applicable only to a limited extent in education... If there had been a general demand for a good education, the present state of things would probably not have existed, but it is notorious that, among a very large proportion of the people, no such demand exists; they have not yet, to use a commercial phrase, acquired the taste for the commodity, and they are not the least aware of the many losses they sustain from the lack of it."2

"It quite disgusts me to hear the cold, calculating economists throwing aside all moral considerations, and with entire ignorance of the state of the people who work in factories, talk of its being an infringement of principle to interfere with labour. Why interfere with the use of capital in any way then? and do we not see laws passed every year to abate the abuse of the application of capital when it is productive of great moral and social evils? If I were free to write I could from my experience make such a statement as would show the fallacious reasons, and bad political economy, of those very economists, who, with their extravagant extensions of their doctrine of laissez faire, bring discredit on the science they cultivate."3

In his last official Report he argued that the principle of laissezfaire was in substance correct but its application was invalidated in the case of factory legislation by one false assumption:

${ }^{1}$ L. Horner, On the Employment of Children in Factories etc., 1840, p. 15.

2 Introduction by L. H. in V. Cousin, op. cit., 1838.

${ }^{3}$ Memoir, Vol. II, p. 158, 23 Feb. 1850, L. H. this daughter Francis. 
"This great experiment in legislation tried as it has been for a quarter of a century, has demonstrated that the non-interference principle of laissez-faire may sometimes be departed from with advantage; an undeniably sound principle in matters of trade when his transactions and the free use of his capital affect the individual alone; but which can never be the case in factories worked by steam engines; for the capital can never be employed in keeping the machinery in motion beyond a limited time, without certain injury to the health and morals of the labourers employed; and they are not in a condition to protect themselves." 1

The clear logic of the last clause, though no one, not even Horner could say it explicitly at that time was that it was "mere sophism" to pretend that the State only needed to protect women and children. The whole of the previous quotation could be read in the same way. There are many instances, especially later in his career, of Horner's scorn of the legalistic assuption that on his 18th birthday a youth becomes magically able to protect his own interests. For example, in his Report for October 1843 he wrote "there can be no such thing as freedom of labour when ... there is such a competition for employment."2 Some of his popularity with the spinners' unions may have sprung from his half-stated belief that the Factory Act could and should protect the whole factory population and not just women and children.

Yet in 1837 he had openly agreed with Nassau Senior that it would be mischievous for the law to try to interfere with adult labour. At that time he had also reinforced Senior's argument that any law which prevented manufacturers running their machinery for more than 12 hours a day would be disastrous both for employers and employees. For this reason he had been an advocate of a relay system of work for children early in his Inspectorship and had opposed the idea of a legally defined normal day. He had changed his mind on both points between the time of his letter to Senior and the early 1840's. In the next decade the Ten Hour Act, the Normal Day and the campaign to stamp out false relays all received his vigorous support. Experience of the factory districts and of the working of the Act may well have helped to convince him that the prosperity of the cotton trade was in no way threatened - he had after all written in his reply to Senior that he found it hard to believe that the profits of the cotton masters were very precariously based when one saw such enormous fortunes made in

${ }^{1}$ L. Horner, Official Report for half year ended 31 October 1859.

${ }^{2}$ L. Horner, Offical Report for half year ended 31 October 1843. 
so short a time in the trade. He may even have been persuaded by his own utilitarian argument. Moreover it is difficult for any man to work for a quarter of a century in a post about which he has reservations. Most people tend to put a large normative and emotional investment into anything which takes up quite so much of their time and energy however indifferent they may have been before becoming involved in the activity. This process is likely to be the more accentuated in an imperious character like Horner who was never comfortable except when he was totally committed to the righteousness of his cause. For whatever combination of reasons Horner seems to have quickly eliminated all the elements of hesitancy in his attitude to the role of the state in industry.

\section{VI}

SOME CONCLUDING REMARKS ON HORNER'S ROLE IN THE DEVELOPMENT OF ENGLISH SOCIAL AND ECONOMIC POLICY

O. R. McGregor has argued following H. L. Beales that from the early 19 th century both social research and social policy were responses to the economic costs of the social wastage inherent in early industrialism. ${ }^{1}$ In this view the great Blue Books of the last century were minute chartings and costings of this economic and social wastage, and thereby indictments of inefficiency. They gave rise to social policies in the Poor Law, the Factory Acts, public health legislation and education reform which began to counter this inefficiency by improving the quality of the human resources available to industrialism. At the same time and for identical reasons the physical sciences were being employed to measure other aspects of national resources; McGregor cites the foundation of the British Association, the Ordnance Survey, the Geological Survey and Meteorological Office as examples. The new bourgeoisie was the driving force behind these enterprises.

Leonard Horner is surely the perfect case of McGregor's argument. $\mathrm{He}$ was one of the scientists responsible for the establishment of the Geological Survey, the major administrator behind the Factory Act and an experienced businessman besides. Horner's own justification of factory legislation was couched precisely in McGregor's terms. Horner should be remembered as part of a remarkable corps of public servants who grappled with the gross problems of early industrialism and began to humanise urban capitalism partly at least in the interests of greater social and commercial efficiency.

1 O. R. McGregor, "Social Research and Social Policy", in: British Journal of Sociology, Vol. VIII, No 2, 1957. McGregor traces his argument to H. L. Beales in, e.g., his Hobhouse Memorial Lecture of 1945. 
Chadwick, Tremenheere, Kay-Shuttleworth, Dr Simon and Dr Southwood Smith are obvious parallel figures. These men were innovators as well as administrators, educated men in the widest sense, prepared to take the concept of natural laws seriously enough to apply it in their study of social problems as well as in the natural sciences. They were open to new ideas and relentless in their application of them. They moulded public opinion, especially among politicians and the professional and business classes both by their arguments and by the striking results of their pioneering work in the new or refurbished departments of government concerned with the condition of the people.

It is surely no accident that by the 1860's the extreme individualist version of political economy was a waning force. The extensions of the Factory Act from the 1860's onwards all received substantial support from the manufacturing classes on precisely the grounds which Horner and his school of thought had been urging for a generation or more. Some of the extensions, like the inclusion of the lace and hosiery trades, were even requested by groups of manufacturers as the only guarantee of fair competition. By the 1880's even the Liberal party, the organ of the industrial middle classes and bastion of individualist principles, was committing itself to an extensive programme of social reform as the necessary basis for an efficient technology and a peaceful political structure. Such a transformation of attitude to the role of government surely owed not a little to men like Leonard Horner. 